\title{
PANDANGAN HUKUM ISLAM DAN HUKUM POSITIF TERHADAP PERNIKAHAN ANAK TIRI PADA MASYARAKAT DESA ROMBUH PAMEKASAN
}

\author{
IMAM HAFAS \\ UIN Sunan Kalijaga Yogyakarta \\ imamhafaz02@gmail.com
}

\begin{abstract}
Marriage is a form of bonding in shaping the life order in a small sphere, that is, a happy family of the hereafter. Talking about a marriage bond that is in the sphere of society, is not free from various problems. Among these are marriages that are not permitted by religion. This actually becomes a problem, where a problem must be solved. Both traditional, custom, and even religion. In this study, the background of the problem is a marriage conducted by a man against his stepson. And done under the hand. The research intends to examine the views of Islamic law and positive law on existing problems. As for some of the issues that can be raised to be able to answer is how is the description of marriage between a man and his stepson? And what are the views of Islamic law and positive law towards marriage between a man and his stepson? In this study, researchers used a qualitative approach to the type of case study research. The data source uses primary and secondary data with data collection techniques of observation, interviews, and documentation. While the data analysis uses inductive and comparative methods. The results of this study are that the practice of marriage in the village of Rembuh is a marriage in the form of dukhul which is prohibited in Islamic law and so is the Marriage Law, this is due to the weak knowledge of marriage law for some people.
\end{abstract}

Keywords: Islamic Law, Positive Law, Married a Stepdaughter.

\begin{abstract}
Abstrak
Pernikahan adalah sebuah bentuk ikatan dalam membentuk tatanan kehidupan dalam lingkup kecil, yaitu keluarga yang bahagia dunia akhirat. Berbicara tentang sebuah ikatan pernikahan yang ada di lingkup masyarakat, tidak luput dari berbagai problem. Di antaranya adalah pernikahan yang tidak diperbolehkan oleh agama. Hal ini justru menjadi sebuah problem, dimana sebuah problem harus diselesaikan. Baik secara adat, kebiasaan, dan bahkan agama. Dalam penelitian ini yang menjadi latar belakang masalah adalah sebuah pernikahan yang dilakukan oleh seorang pria terhadap anak tirinya. Dan dilakukan dibawah tangan. Penelitian
\end{abstract}


bermaksud mengkaji tentang pandangan hukum Islam dan hukum positif terhadap permasalahan yang ada. Adapun beberapa pokok permasalahan yang dapat diangkat untuk mampu menjawab adalah bagaimana deskripsi pernikahan antara seorang pria dengan anak tirinya? Dan bagaimana pandangan hukum Islam dan hukum positif terhadap pernikahan antara seorang pria dengan anak tirinya?. Dalam penelitian ini, peneliti menggunakan pendekatan kualitatif dengan jenis penelitian studi kasus. Adapun sumber data menggunakan data primer san sekunder dengan tehnik pengumpulan data observasi, wawancara, dan dokumentasi. Sedangkan analisis data menggunakan metode induktif dan metode komparatif. Hasil dari penelitian ini yaitu praktik pernikahan yang dilakukan di desa Rembuh merupakan pernikahan $b a^{\prime} d a$ dukhul yang dalam hukum Islam itu dilarang dan begitu juga dalam Undang-Undang Perkawinan, hal ini disebabkan oleh lemahnya pengetahuan tentang hukum pernikahan bagi sebagian masyarakatnya.

Kata Kunci: Hukum Islam, Hukum Positif, Menikahi Anak Tiri.

\section{PENDAHULUAN}

Menurut fitrahnya, manusia dilengkapi Tuhan dengan kecendrungan seks (libido seksualitas). Sudah menjadi kodrat alam, bahwa dua orang manusia dengan jenis kelamin yang berlainan, seorang perempuan dan laki-laki ada daya tarik satu sama lainnya untuk hidup bersama. ${ }^{1}$ Karena Islam adalah agama yang fitrah, ${ }^{2}$ maka Tuhan menyediakan wadah yang legal untuk terselenggaranya penyaluran tersebut yang sesuai dengan derajat manusia.

Perkawinan merupakan jalan untuk menyalurkan naluriah manusiawi, untuk memenuhi tuntutan nafsu syahwatnya dengan tetap memelihara keselamatan agama yang bersangkutan. ${ }^{3}$ Sebagaimana yang kita ketahui bahwasanya perkawinan adalah merupakan salah satu hal yang penting dalam kehidupan manusia, terutama dalam pergaulan hidup masyarakat. ${ }^{4}$ Perkawinan adalah merupakan jalan yang amat mulia untuk mengatur kehidupan rumah tangga dan keturunan.

Hukum Islam dan undang-undang yang berlaku di Indonesia telah mengatur agar perkawinan itu dilaksanakan melalui jalan akad nikah atau perikatan hukum antara pihak-pihak yang bersangkutan yang disaksikan oleh dua orang laki-laki dengan memenuhi syarat-syarat dan rukun-rukun yang ada di dalamnya, sehingga perkawinan itu menjadi sah.

Undang-Undang Nomor 1 Tahun 1974 Pasal 1 menyebutkan bahwa tujuan diadakannya perkawinan adalah untuk membentuk rumah tangga yang bahagia,

1 Agus Hermanto, Larangan Perkawinan: dari Fikih, Hukum Islam, hingga Penerapannya dalam Legislasi Perkawinan Indonesia, Cet. Ke-1, (Yogyakarta: Lintang Rasi Aksara Books, 2016),1 2011), 11.

2 Djalaluddin al-Ra'uf bin Dahlan, Aturan Pernikahan dalam Islam, (Jakarta: Jal Publishing,

${ }^{3}$ Agus Hermanto, Larangan Perkawinan, 2.

${ }^{4}$ Agus Hermanto, Larangan Perkawinan, 2. 
kekal, berdasarkan Ketuhanan Yang Maha Esa. ${ }^{5}$ Perkawinan yang bahagia adalah perkawinan yang sejahtera lahir dan batin. Sebuah perkawinan yang di dalamnya menyatu segala cipta, rasa dan karsa ke dalam satu tujuan, akan mengantarkan pada terciptanya sebuah struktur rumah tangga yang berpijak pada kasih sayang, ketenteraman dan ridlo Allah SWT. ${ }^{6}$ Inilah yang dalam pandangan Islam disebut dengan istilah keluarga sakinah.

Pernikahan di dalam Islam diharapkan dapat membentuk keluarga yang sakinah, mawaddah, wa rahmah. ${ }^{7}$ Ciri keluarga sakinah ini adalah adanya cinta kasih yang permanen antara suami-istri. Ciri ini dibangun atas dasar prinsip bahwa membangun keluarga adalah amanat yang masing-masing pihak terikat untuk menjalankan sesuai dengan ajaran Allah SWT. Selain itu, keluarga sakinah pada dasarnya memperhatikan prinsip kesetaraan, saling membantu dan melengkapi dalam pembagian tugas antara suami-istri sesuai kesepakatan bersama. $^{8}$

Di samping perkawinan itu harus memenuhi rukun dan syaratnya, perkawinan yang akan dilangsungkan harus didasarkan atas persetujuan kedua calon mempelai sebagaimana dijelaskan dalam Pasal 6 Undang-Undang No. 1 Tahun 1974 tentang Perkawinan. Selain itu, seorang lelaki tidak boleh sembarangan menikahi perempuan, sebab di dalam ajaran Islam telah digariskan tentang siapa-siapa yang boleh dinikahi dan yang tidak boleh dinikahi. Artinya, Islam benar-benar menjaga kesucian keturunan (nasal) umatnya.

Seandainya Islam tidak mengatur pernikahan dengan sebaik-baiknya, niscaya setiap orang bisa menikahi siapa saja, dan hal ini pasti akan menimbulkan permasalahan. Seperti yang terjadi baru-baru ini di Desa Rombuh Kecamatan Palengaan Kabupaten Pamekasan, yakni pernikahan yang dilakukan dengan anak tirinya. Untuk melangsungkan pernikahannya mereka mencari seorang Kiai yang berkenan menikahkan mereka dengan menyembunyikan status kedua mempelai dan memberi imbalan agar pernikahan bisa berlangsung seperti yang diinginkan oleh kedua mempelai tersebut.

Untuk menghasilkan penelitian dari sudut pandang hukum, maka masalah pernikahan antara ayah dan anak tiri tersebut akan dilakukan analisis dengan menggunakan konsep pernikahan dalam hukum Islam dan undang-undang pernikahan di Indonesia, sehingga mampu menjawab dari aspek hukum Islam dan hukum positif.

\section{METODE PENELITIAN}

\footnotetext{
5 Tim Penyusun, Undang-Undang Perkawinan di Indonesia (Surabaya: Arkola, 1974), 5.

${ }^{6}$ Anshari Thayib, Struktur Rumah Tangga Muslim (Surabaya: Risalah Gusti, 1991),22.

${ }_{7}^{7}$ Agus Hermanto, Larangan Perkawinan, 5.

8 Abdul Hakam al-Sha'idi, Menuju Keluarga Sakinah, terj. Uqinu Attaqi, (Yogyakarta: Pustaka Pelajar, 1995),119.
} 
Jenis penelitian ini adalah studi kasus atau case study, yakni suatu bentuk penelitian yang intensif, terintegrasi, dan mendalam. ${ }^{9}$ Penelitian ini bersifat eksploratif dan mendalam sehingga menghasilkan gambaran peristiwa tertentu. Subjek yang diteliti terdiri atas satu unit atau satu kesatuan unit yang dipandang sebagai kasus.

Pendekatan yang digunakan dalam penelitian ini adalah pendekatan kualitatif, yaitu suatu penelitian yang digunakan untuk meneliti kondisi objek yang alamiah, peneliti merupakan instrumen kunci, tehnik pengumpulan data yang dilakukan adalah triangulasi, analisis datanya bersifat induktif, dan hasilnya lebih menekankan makna dari pada generalisasi. ${ }^{10}$

Analisis data dalam penelitian ini menggunakan dua analisis, yaitu analisis induktif dan analisis komparatif. Dimana yang dimaksud dalam analisis induktif disini adalah suautu metode yang berangkat dari fakta-fakta yang khusus, peristiwa-peristiwa yang kongkrit, dan kemudian ditarik terhadap generalisasi yang mempunyai sifat umum. ${ }^{11}$ Analisis induktif dapat dijabarkan menjadi tiga tahap atau prosedur. yaitu, reduksi data, penyajian data, dan verifikasi data. Sedangkan analisis komparatif yaitu suatu metode yang dilakukan dengan cara membandingkan kesamaan pandangan dan perubahan-perubahan pandangan orang terhadap kasus, peristiwa, atau ide. ${ }^{12}$ Metode ini akan digunakan untuk mengkomparasikan antara tinjauan hukum Islam dan hukum positif tentang pernikahan antara pria dengan anak tirinya, sehingga dapat ditemukan adanya persamaan, perbedaan, kelebihan, dan kelemahan antara keduanya.

\section{HASIL DAN PEMBAHASAN \\ TERMINOLOGI PERKAWINAN}

Perkawinan merupakan padanan dari kata nikah yang berasal dari bahasa Arab, al-nikāh. Secara etimologi, nikah adalah mengumpulkan. Sedangkan menurut syara', perkawinan adalah akad yang sudah dikenal dan telah memenuhi rukunrukun serta syarat tertentu untuk berkumpul;13 atau akad yang mengandung ketentuan hukum kebolehan hubungan seksual dengan lafaz nikah atau dengan kata-kata yang semakna dengannya. ${ }^{14}$

Menurut istilah fiqih, pernikahan berasal dari kata "nikah". "Nikah" menurut bahasa memiliki arti yang sebenarnya (haqiqat) dan arti kiasan (majāz). Arti yang sebenarnya dari "nikah" ialah "dam" artinya "menghimpit" atau "menindih" atau

${ }^{9}$ Sumadi Suryabrata, Metode Penelitian, (Jakarta: Raja Grafindo Persada, 2010), 80.

${ }^{10}$ Sugiyono, Metode Penelitian kuantitatif, kualitatif, dan R \& D, (Bandung: Alfabeta, 2009), 9.

${ }_{11}$ Sutrisno Hadi, Metodologi Research, (Yogyakarta: Andi Offset, 1986), 42.

12 Suharsimi Arikunto, Prosedur Penelitian:Suatu Pendekatan Praktik, (Bandung: Remaja Rosdakarya, 2006), 267.

13 Taqiyuddin Abu Bakar Muhammad al-Husaini, Kifayat al-Akhyar, (Beirut: Dar al-Kutub alIlmiyah, 2001), 460.

${ }^{14}$ Rahman Ghazaly, Fiqh Munakahat, (Jakarta: Kencana, 2003), 10. 
"berkumpul", sedang arti kiasannya ialah "watha" artinya 'setubuh" atau "aqad" artinya "mengadakan perjanjian pernikahan".15

Menurut Undang-Undang Perkawinan Nomor 1 Tahun 1974 Pasal 1: "Perkawinan ialah ikatan lahir bathin antara seorang pria dan wanita sebagai suami-isteri dengan tujuan membentuk keluarga (rumah tangga) yang bahagia dan kekal berdasarkan ketuhanan Yang Maha Esa".16 Peraturan perundang-undangan Negara yang mengatur perkawinan di Indonesia adalah:

1) Undang-Undang Nomor 32 tahun 1954 tentang penetapan berlakunya Undang-Undang Republik Indonesia tanggal 21 November 1946 Nomor 22 Tahun 1946 tentang pencatatan nikah, talak dan rujuk di seluruh daerah luar Jawa dan Madura. Sebagaimana bunyinya UU ini hanya mengatur tata cara pencatatan nikah, talak dan rujuk, tidak materi perkawinan secara keseluruhan.

2) Undang-Undang No 1 Tahun 1974 tentang perkawinan, yang merupakan hukum materiil dari perkawinan dengan sedikit menyinggung acaranya.

3) Peraturan pemerintah No. 9 Tahun 1975 tentang pelaksanaan Undang-Undang Nomor 1 Tahun 1974, tentang perkawinan. PP ini hanya memuat pelaksanaan dari beberapa ketentuan yang terdapat dalam UU Nomor 1 Tahun 1974.

4) Undang-Undang Nomor 7 Tahun 1989 tentang Peradilan Agama, sebagian dari materi Undang-Undang ini memuat aturan yang berkenaan dengan tata cara (hukum formil) penyelesaian sengketa perkawinan di pengadilan agama. ${ }^{17}$

Sedangkan menurut Kompilasi Hukum Islam (KHI) disebutkan bahwa perkawinan adalah pernikahan, yaitu akad yang sangat kuat atau mitsâqan ghalîdhan untuk mentaati perintah Allah dan melaksanakannya merupakan ibadah. ${ }^{18}$

Dari definisi perkawinan di atas, dapat ditarik kesimpulan bahwa perkawinan adalah suatu perjanjian (akad) yang menghalalkan hubungan seksual antara seorang pria dan wanita yang bukan mahramnya yang merupakan kehendak kemanusiaan dan pemenuhan kebutuhan jasmani maupun rohani yang bertujuan membentuk keluarga yang harmonis.

Perkawinan merupakan salah satu sunnatullah yang berlaku pada semua makhluk Tuhan, baik pada manusia, hewan maupun tumbuh-tumbuhan. Perkawinan merupakan cara yang dipilih oleh Allah sebagai jalan bagi manusia

15 Mukhtar Kamal, Asas-asas Hukum Islam tentang Perkawinan, (Jakarta: Bulan Bintang, 1985),1.

16 Soemiyati, Hukum Perkawinan Islam dan Undang-Undang Perkawinan, (Yogyakarta: Liberty, 1997), 9.

17 Tim Penyusun, Undang-Undang Perkawinan di Indonesia, (Surabaya: Arkola, 2005), 5.

18 Rahman Ghazaly, Fiqh Munakahat,10. 
untuk beranak pinak, berkembang biak, dan melestarikan hidupnya setelah masing-masing pasangan siap melakukan perannya yang positif dalam mewujudkan tujuan perkawinan. Dengan kata lain Allah tidak menjadikan manusia seperti makhluk lainnya yang hidup bebas mengikuti nalurinya dan berhubungan secara anarkhi tanpa aturan. Manusia sebagai makhluk berketuhanan tak lepas dari kewajiban kemanusiaan untuk mengadakan perkawinan yakni upaya membina bahtera rumah tangga. Pada hakekatnya perkawinan dalam Islam merupakan salah satu sunnatullah pada hamba-Nya, dengan perkawinan Allah menghendaki agar mereka mengemudikan bahtera rumah tangga. Islam mengajarkan kepada umatnya bahwa Allah SWT menciptakan segala sesuatu berpasang-pasangan, sebagaimana dijelaskan di dalam QS. Al-Dzariyat (51): 49.19

Konsepsi perkawinan Islam lebih ditekankan pada aspek kelembagaan, dalam arti, menguraikan konsepsi perkawinan sebagai suatu lembaga sosial yang mewadahi aktivitas seksual manusia (umat Islam) sekaligus lembaga yang menjadikan halal hubungan seksual antara laki-laki dan perempuan yang bukan muhrimnya. Penghalalan hubungan seksual tidak dapat diartikan semata-mata untuk kesenangan syahwat atau sebagai penyaluran hawa nafsu, karena dalam perkawinan tujuan reproduksi untuk mendapatkan anak yang sholeh adalah yang lebih diutamakan.

Pada dasarnya Islam mengkonsepsi bahwa perkawinan merupakan suatu jalan terbaik yang dapat menjauhkan diri seseorang, pribadi muslim, dari segala dorongan syahwat yang dapat mendekatkan pada perbuatan zina. Islam juga menkonsepsikan perkawinan sebagai sesuatu yang sesuai dengan fitrah manusia yang dikodratkan Tuhan untuk hidup berpasang-pasangan. Oleh karenanya, jika dikaji secara seksama akan diketahui bahwa perkawinan adalah suatu akad yang menghalalkan hubungan kelamin antara pria dan wanita dengan tujuan membentuk kehidupan rumah tangga dan mendapatkan keturunan yang diridhoi oleh Allah SWT.

Ditilik dari dimensi adanya kepastian hukum dan pemakaian perkataan "nikah" dalam al-Qur'an dan hadis, nikah dalam artian "akad" (perjanjian perikatan) agaknya lebih cocok dipakai dari pada "nikah" dalam artian "setubuh" (hubungan seks). ${ }^{20}$ Karenanya rumusan lengkap pernikahan menjadi suatu perjanjian atau kesepakatan untuk bercampur atau bergaul dengan sebaik-baiknya antara seorang laki-laki dan seorang perempuan dalam status suami-isteri dengan sepenuhnya mempertimbangkan kualifi-kasi rukun dan syaratnya. ${ }^{21}$ Dengan peraturan perkawinan tersebut, maka tertutuplah hubungan antara pria dan

${ }^{19}$ QS. Al-Dzuriyat (51): 49.

20 Mukhtar Kamal, Asas-Asas Hukum Islam Tentang Perkawinan,2

${ }_{21}$ Chuzaimah T. Yanggo dan A. Hafiz Anshari A. Z. (Ed.), Problematika Hukum Islam Komtemporer, (Jakarta: Sinar Grafika, 2000),98. 
wanita yang dilakukan dengan cara yang tidak halal. Dengan demikian perkawinan yang sah akan berakibat terhadap keturunan yang sah pula.

Secara simbolik, konsepsi perkawinan Islam mengandung makna sacral transcendental, yakni makna-makna yang dipercaya umatnya sebagai sesuatu yang menyatu dengan eksistensi Tuhan (Allah), sekaligus mengandung makna profan, yaitu makna seksual yang melekat dalam aktifitas seksual manusia di dunia yang dapat menimbulkan kenikmatan fisik biologis bagi mereka yang melakukannya.

\section{HUKUM PERKAWINAN}

Islam menganjurkan kepada umatnya untuk melakukan perkawinan, namun demikian ulama berbeda pendapat dalam menentukan hukum perkawinan. Adapun pelaksanaan perkawinan jika dihubungkan dengan kondisi seseorang meliputi lima hokum, yaitu: Pertama, Wajib Yaitu perkawinan yang harus dilakukan oleh seseorang yang memiliki kemampuan untuk menikah serta memiliki kemampuan secara nafsu biologis dan khawatir benar dirinya akan melakukan perbuatan zina manakala tidak melakukan pernikahan. Karena satusatunya sarana untuk menghindarkan diri dari perbuatan zina itu adalah nikah, maka menikah menjadi wajib bagi orang yang seperti ini. ${ }^{22}$ Sebagaimana firman Allah dalam QS. al-Nur ayat 24: (32).

Kedua, Haram yaitu perkawin diharamkan bagi orang yang tahu bahwa dirinya tidak mampu melaksanakan hidup rumah tangga, melaksanakan kewajiban lahir seperti memberi nafkah pakaian, tempat tinggal dan sebagainya, kewajiban bathin seperti menggauli istri serta nafsunya tidak mendesak. ${ }^{23}$ Bagi orang yang tergolong haram beristeri, harus menghindari perni-kahan sebelum dapat membersihkan niatnya. Pernikahan menjadi haram, apabila seseorang yang mengawini seseorang hanya dengan maksud menganiayanya atau memperolokoloknya, maka haramlah baginya untuk kawin. Demikian juga apabila seseorang baik wanita ataupun pria, yang mengetahui dirinya mempunyai penyakit atau kelemahan yang mengakibatkan tidak bisa melaksanakan tugasnya sebagai suami/isteri dalam pernikahan, sehingga mengakibatkan salah satu pihak menjadi menderita atau karena penyakitnya itu menyebabkan pernikahan itu tidak bisa mencapai tujuannya. ${ }^{24}$

Ketiga, Sunnah, Adapun bagi yang nafsunya sudah mendesak dan mampu kawin, tetapi masih dapat menahan dirinya dari perbuatan zina, maka hukumnya sunnah kawin. ${ }^{25}$ Pernikahan sunnah adalah pernikahan yang dianjurkan kepada seseorang yang mampu untuk melakukan pernikahan dan memiliki nafsu biologis, tetapi dia merasa mampu untuk menghindarkan dirinya dari kemungkinan

\footnotetext{
22 Taqiyuddin Abi Bakar Muhammad al-Husaini, Kifayat al-Akhyar, 426.

23 Taqiyuddin Abi Bakar Muhammad al-Husaini, Kifayat al-Akhyar, 462.

24 Soemiyati, Hukum Perkawinan Islam, 21

25 Taqiyuddin Abi Bakar Muhammad al-Husaini, Kifayat al-Akhyar, 462.
} 
melakukan zina. Orang yang memiliki kemampuan dalam bidang ekonomi, serta sehat jasmani dalam artian memiliki nafsu syahwati, maka dia tetap dianjurkan supaya menikah meskipun orang yang bersangkutan merasa mampu untuk memelihara kehormatan dirinya dari kemungkinan melakukan pelanggaran seksual. ${ }^{26}$

Keempat, Mubah yakni bagi orang yang tidak ada halangan untuk kawin dan dorongan untuk kawin belum membahayakan dirinya, maka orang tersebut belum wajib kawin dan tidak haram bila tidak kawin. ${ }^{27}$

Kelima, Makruh yaitu pernikahan yang dilakukan oleh orang yang tidak memiliki kemampuan biaya hidup meskipun memiliki kemampuan biologis, atau tidak memiliki nafsu biologis meskipun memiliki kemampuan ekonomi, tetapi ketidakmampuan biologis atau ekonomi itu tidak sampai membahayakan salah satu pihak khususnya isteri. ${ }^{28}$ Menikah hukumnya makruh bagi orang yang tidak mampu memberikakn nafkah bagi calon keluarganya. ${ }^{29}$

Sahnya suatu perkawinan menurut hukum Islam dilaksanakan dengan memenuhi syarat-syarat dan rukun perkawinan. Yang dimaksud dengan rukun perkawinan ialah hakikat dari perkawinan itu sendiri, jadi tanpa adanya rukun, perkawinan tidak mungkin dilaksanakan. Sedang yang dimaksud dengan syarat ialah sesuatu yang harus ada dalam perkawinan tetapi tidak termasuk hakikat perkawinan itu sendiri. Kalau salah satu dari syarat dari perkawinan itu tidak terpenuhi, maka perkawinan itu tidak sah. ${ }^{30}$ Adapun rukun-rukun perkawinan ialah, calon suami, calon isteri, wali nikah, dua orang saksi, ijab dan kabul. ${ }^{31}$

\section{HUKUM MENIKAHI ANAK TIRI}

Dalam sebuah atsar dinyatakan bahwa menikah dengan anak tiri tidaklah haram dengan syarat anak tiri yang akan dinikahi tidak berada dalam asuhan bapak tirinya walaupun sudah terjadi dukhul dengan ibu kandung dari anak tiri tersebut, ini berdasarkan riwayat sahabat pada zaman Khalifah Ali bin Abi Tholib.

Al-Hafidh Ibnu Hajar berkata: "Diriwayatkan oleh 'Abdurrazzaaq, Ibn alMundzir dan yang lainnya dari jalan Ibrahiim bin 'Ubaid, dari Maalik bin Aus, ia berkata: Aku pernah mempunyai isteri yang melahirkan, lalu isteriku itu meninggal dan aku pun sedih. Maka aku menemui 'Ali bin Abi Thalib. Ia berkata kepadaku: 'Ada apa denganmu?' Aku pun mengkhabarkan kepadanya apa yang terjadi. 'Ali lalu bertanya: 'Apakah istrimu mempunyai anak perempuan, yaitu dari selainmu (anak tiri)?' Aku jawab: 'Ya'. Ia kembali bertanya: 'Apakah anak

26 Muhammad Amin Suma, Hukum Keluarga Islam di Indonesia, (Jakarta: Raja Grafindo Persada, 2004),92.

27 Taqiyuddin Abi Bakar Muhammad al-Husaini, Kifayat al-Akhyar, 462.

${ }^{28}$ Muhammad Amin Suma, Hukum Keluarga Islam di Indonesia, 92.

${ }^{29}$ Taqiyuddin Abi Bakar Muhammad al-Husaini, Kifâyat al-Akhyâr, 462.

30 Soemiyati, Hukum Perkawinan Islam, 30.

${ }^{31}$ Sulaiman Ibn Muhammad Ibn Umar al-Bujairimi, Al-Bujairimi 'ala al-Khatib, Juz IV, (Beirut: Dar al-Kutub al-Ilmiyah, 1996), 121. 
perempuan tirimu itu dalam asuhanmu?' Aku jawab: 'Tidak, ia ada di Thaaif'. Ia berkata: 'Nikahilah ia!'Aku berkata: 'Lantas bagaimana dengan ayat \{waraba'ibukum\} (anak perempuan/tiri dari istri yang telah aku campuri)?' 'Ali berkata: 'Ia tidak dalam asuhanmu'.32

Berdasarkan atsar di atas diketahui bahwa menikahi anak tiri itu adalah boleh selama anak tiri tersebut tidak berada dalam asuhan ayah tirinya. Namun demikian, di dalam kitab al-Majmu' disebutkan bahwa dalil kita adalah apa yang diriwayatkan Abdullah Ibn Amr Ibn al-Ash bahwa Rasulullah bersabda: "Barang siapa yang menikah dengan seorang perempuan, kemudian mentalaknya sebelum dikumpuli, maka ibu perempuan itu haram dinikahi, tetapi anaknya tidak haram baginya". ${ }^{33}$ Penjelasan tersebut dapat mengantarkan pada pemahaman (mafhum mukhafalah) bahwa anak tiri tidaklah boleh atau haram hukumnya dinikahi oleh bapak tirinya karena sebab pernikahan (ba'da al-dukhul) dengan ibu dari anak tersebut.

\section{ANALISIS HUKUM ISLAM TERHADAP PERNIKAHAN ANTAR SEORANG PRIA DENGAN ANAK TIRINYA}

Syariat Islam telah menjadikan pernikahan menjadi salah satu hal yang perlu difahami hukum-hukumnya secara menyeluruh dan mendalam. Karena ketika tidak difahami secara mendalam maka akibat yang ditimbulkan setelah pernikahan akan ada masalah seperti waris, nasab, dan lain sebagainya. Seperti halnya dalam masalah pernikahan seorang bapak dengan anak tirinya. Hal ini terdapat penjelasan dalam QS. An-Nisa ayat4 : (23).

Ayat tersebut secara tegas menyatakan bahwa seorang laki-laki dilarang/haram menikahi anak istri (dari suami yang lain/anak tiri) jika terkumpul padanya dua kondisi, yakni: (1) Anak tiri dalam asuhan atau pemeliharaan ayah tirinya. (2) Ayah tiri (si laki-laki) tersebut telah mencampuri (menjima') ibu tirinya.

Jika terkumpul dua kondisi ini, maka haram bagi ayah tiri menikahi anak tirinya, karena statusnya adalah mahram baginya. Namun jika dua kondisi tersebut tidak terpenuhi atau hanya satu kondisi saja yang terpenuhi, maka tidak mengapa jika ayah tiri menikahi anak tiri. Pendapat ini merupakan pendapat dari AmiirulMukminiin 'Aliy bin Abi Thaalib radliyallaahu 'anhu, Abu Muhammad bin Hazm rahimahullah, dan ternukil dari Malik bin Anas rahimahullah.

Larangan untuk melakukan pernikahan disebabkan suatu hubungan darah yang sangat dekat dan juga larangan sebab hubungan pernikahan telah termuat dalam QS. al-Nisa' ayat 23. Berdasarkan dari hasil penelitian di atas diketahui bahwa yang mendasari pernikahan seorang bapak dengan anak tirinya di desa Rombuh kecamatan Rombuh adalah karena adanya rasa cinta, besarnya nafsu

\footnotetext{
32 Ibnu Hajar al-'Asqalami, Fath alBari, Juz 9, (Beirut: Dar al-Fikr, t.th.), 158.

33 Imam al-Nawawi, Al-Majmu' Syarh al-Muhadzdzab, Juz 16, (Beirut: Dar al-Fikr, t.th.), 218.
} 
biologis kedua mempelai dan ketercelaan perilaku mereka. Dalam pernikahan seorang bapak dengan anak tirinya $b a^{\prime} d a$ al-dukhul yang merupakan pernikahan yang tidak memenuhi syarat sahnya suatu pernikahan, maka secara otomatis syarat-syarat untuk menghalalkan hubungan suami istri juga tidak akan terpenuhi.

Suatu pernikahan dapat menjadi haram bagi orang yang mengetahui bahwa dirinya tidak mampu melaksanakan hidup berumah tangga, melaksanakan kewajiban lahir seperti memberikan nafkah pakaian, tempat tinggal, dan kewajiban batin mencampuri serta nafsunya tidak mendesak. Meskipun pernikahan seorang bapak dengan anak tirinya ba'da al-dukhul dilakukan oleh orang yang mempunyai kemampuan serta tanggung jawab untuk melaksanakan keawajiban-kewajiban dalam rumah tangga dan pernikahan itu tidak mengandung unsur penelantaran bagi dirinya dan istrinya, bukan berarti pernikahan seorang bapak dengan anak tirinya $b a^{\prime} d a$ al-dukhul diperbolehkan, melainkan semua yang menyangkut masalah pernikahan, sudah ada ketentuan dan bagiannya masingmasing.

Pernikahan seorang bapak dengan anak tirinya ba'da al-dukhul di Desa Rombuh ini termasuk dalam ketentuan-ketentuan larangan pernikahan. Dalam hukum pernikahan Islam (Fiqih Munakahah) wanita yang haram dinikahinya berlaku pada lima sebab. Walaupun pada dasarnya tiap laki-laki Islam boleh melakukanpernikahan dengan wanita mana saja namun demikian juga di berikan batasan-batasan tertentu. ${ }^{34}$

Pembatasan tersebut bersifat larangan. Sifat larangan ini disebabkan karena antara lain: beda agama, hubungan darah, hubungan susuan, dan hubungan semenda, yang itu sifatnya untuk selama lamanya. Di samping juga ada laranganlarangan yang sifatnya sementara.

Berdasarkan penjelasan mengenai larangan pernikahan menurut Syara', baik yang terdapat di dalam al-Qur'an, al-Hadist maupun yurisprudensi hukum Islam lainnya, maka dapat diketahui bahwa pernikahan seorang bapak dengan anak tirinya $b a^{\prime} d a$ al-dukhul yang terjadi di Desa Rombuh adalah pernikahan yang tidak diperbolehkan atau diharamkan dalam hukum Islam karena termasuk dalam larangan pernikahan yang bersifat abadi atau selamanya (mahrom muabbad) karena adanya faktor mushaharah (pernikahan) dan radha'. ${ }^{35}$

Sedangkan analisis hukum positif terhadap pernikahan antara seorang pria dengan anak tirinya di Desa Rambuh Palengaan Pamekasan. Yaitu suatu pernikahan dapat dikatakan "sah" menurut hukum positif di Indonesia manakala pernikahan itu dilaksanakan menurut tata tertib aturan UU No 1 Tahun 1974. Pada

34 Soemiati, Hukum Perkawinan dan Undang-Undang Perkawinan Nomor 1 Tahun 1974, (Yogyakarta: Liberty, 1999),67.

35 H.S.A Al-Hamdani, Risalah Nikah, (Jakarta: Pustaka Amani, 2002), 44. Agus Hermanto, Larangan Perkawinan: dari Fikih, Hukum Islam, hingga Penerapannya dalam Legislasi Perkawinan Indonesia, Cet. Ke-1, (Yogyakarta: Lintang Rasi Aksara Books, 2016), 13. 
tanggal 2 Januari 1974 telah disahkan oleh presiden RI suatu Undang-Undang Pernikahan Nasional, yaitu Undang-Undang No 1 Tahun 1974 dengan peraturan pelaksanaan PP. Nomor 9 Tahun 1975. Maka bagi warga negara Indonesia berlakulah UU tentang Pernikahan No 1 Tahun 1974 dengan pelaksanaannya PP. No. 9 Tahun 1975 tersebut.

Berdasarkan ketentuan pasal 2 ayat 1 Undang-Undang No 1 tahun 1974, pernikahan dianggap sah apabila dilaksanakan menurut hukum agamannya dan kepercayaannya masing-masing. Pernikahan yang sah menurut hukum pernikahan nasional adalah pernikahan yang dilaksanakan menurut tata tertib aturan hukum yang berlaku dalam agama Islam, Kristen/Katolik, Hindu ataupun Budha. Kata "hukum masing-masing agamanya" berarti hukum dari salah satu agama itu masing-masing, bukan berarti "hukum agamanya masing-masing" yaitu hukum agama yang dianut oleh kedua mempelai.

Menurut Undang-Undang Nomor 1 Tahun 1974 tentang Perkawinan, syaratsyarat pernikahan diatur dalam pasal 6 yang berbunyi:

a) Pernikahan harus didasarkan atas persetujuan kedua calon mempelai.

b) Untuk melangsungkan pernikahan seorang yang belum mencapai umur 21 (dua puluh satu) tahun harus mendapat izin kedua orang tua.

c) Dalam hal salah seorang dari kedua orang tua telah meninggal dunia atau dalam keadaan tidak mampu menyatakan kehendaknya.

d) Dalam hal kedua orang tua meninggal dunia atau dalam keadaan tidak mampu untuk menyatakan kehendaknya maka izin diperoleh dari wali, orang yang memelihara atau keluarga yang mempunyai hubungan darah dalam garis keturunan lurus ke atas selama mereka masih hidup dalam keadaan dapat menyatakan kehendaknya.

e) Dalam hal perbedaan pendapat antara orang-orang yang disebut dalam pasal (2), (3) dan (4) pasal ini, atau salah seorang atau lebih diantara mereka tidak menyatakan pendapatnya, maka pengadilan dalam daerah hukum tempat tinggal orang yang akan melangsungkan pernikahan atas permintaan yang akan melangsungkan pernikahan atas permintaan tersebut dapat memberikan izin setelah lebih dulu mendengar orang-orang tersebut dalam ayat (2), (3) dan (4) pasal ini.

f) Ketentuan tersebut ayat (1) sampai dengan ayat (2) pasal ini berlaku sepanjang hukum masing-masing agamanya dan kepercayaan itu dari yang bersangkutan tidak menentukan lain. ${ }^{36}$

Dalam UU Nomor 1 Tahun 1974 Pasal (8) disebutkan bahwa pernikahan dilarang antara dua orang yang:

a) Berhubungan darah dalam garis keturunan lurus ke bawah ataupun ke atas.

${ }^{36}$ Undang-Undang Nomor 16 Tahun 2019 perubahan atas Undang-Undang Nomor 1 Tahun 1974 tentang Perkawinan. 
b) Berhubungan darah dalam garis keturunan menyamping, yaitu antara saudara, antara seorang dengan saudara orang tua dan antara seorang dengan saudara neneknya.

c) Berhubungan semenda.

d) Berhubungan susuan.

e) Berhubungan saudara dengan isteri atau sebagai bibi atau kemenakan dari isteri dalam hal seorang suami beristeri lebih dari seorang.

f) Mempunyai hubungan yang oleh agamanya atau peraturan lain yang berlaku dilarang kawin.

Berdasarkan UU Nomor 1 Tahun 1974 Pasal (8), maka pernikahan antara seorang pria dengan anak tirinya di Desa Rombuh Palengaan Pamekasan termasuk penikahan yang tidak sah atau dilarang, karena pada poin (a) disebutkan secara tegas tentang faktor "berhubungan darah dalam garis keturunan lurus ke bawah ataupun ke atas" yang menjadi penghalang sahnya pernikahan tersebut.

\section{PENUTUP}

Pernikahan antara seorang pria dengan anak tirinya yang terjadi di Desa Rombuh Kecamatan Palengaan Kabupaten Pamekasan dilaksanakan di Kabupaten Sampang kepada seorang kiai kampung dengan maskawin Rp 50.000,- Pernikahan itu terjadi ba'da dukhul. Dalam pandangan hukum Islam, pernikahan seorang pria dengan anak tirinya ba'da al-dukhul di Desa Rombuh merupakan pernikahan yang dilarang atau diharamkan oleh syari'at Islam, karena pernikahan tersebut termasuk dalam larangan pernikahan abadi/selamanya (mahram mu'abbad) disebabkan adanya faktor mushaharah atau faktor hubungan perkawinan sebagaimana disebutkan dalam QS. al-Nisa' ayat 23, yakni: (a) anak tiri dalam asuhan atau pemeliharaan ayah tirinya, (b) ayah tiri (si laki-laki) tersebut telah mencampuri (menjima') ibu tirinya.

Dalam pandangan hukum positif terutama menurut UU Nomor 1 Tahun 1974 Pasal (8), maka pernikahan antara seorang pria dengan anak tirinya di Desa Rombuh Palengaan Pamekasan termasuk penikahan yang tidak sah atau dilarang, karena pada poin (a) disebutkan secara tegas tentang faktor "berhubungan darah dalam garis keturunan lurus ke bawah ataupun ke atas" yang menjadi penghalang sahnya pernikahan tersebut.

\section{DAFTAR PUSTAKA}

Al-'Asqalami Ibnu Hajar. Fath al-Bari. Juz 9. Beirut: Dar al-Fikr.t.th

Al-Husaini Taqiyuddin Abu Bakar Muhammad. Kifayat al-Akhyar. Beirut: Dar alKutub al-Ilmiyah. 2001 
Al-Nawawi Imam. Al-Majmu' Syarh al-Muhadzdzab. Juz 16. Beirut: Dar al-Fikr. t.th. Al-Ra'uf bin Dahlan Djalaluddin. Aturan Pernikahan dalam Islam. Jakarta: Jal Publishing. 2011.

Al-Sha'idi Abdul Hakam. Menuju Keluarga Sakinah. terj. Uqinu Attaqi. Yogyakarta: Pustaka Pelajar. 1995.

Amin Suma Muhammad. Hukum Keluarga Islam di Indonesia. Jakarta: Raja Grafindo Persada. 2004.

Arikunto Suharsimi. Prosedur Penelitian: Suatu Pendekatan Praktik. Bandung: Remaja Rosdakarya. 2006.

Ghazaly Rahman. Fiqh Munakahat. Jakarta: Kencana. 2003.

H.S.A Al-Hamdani. Risalah Nikah. Jakarta: Pustaka Amani. 2002.

Hadi Sutrisno. Metodologi Research. Yogyakarta: Andi Offset. 1986.

Hermanto Agus. Larangan Perkawinan: dari Fikih, Hukum Islam, hingga Penerapannya dalam Legislasi Perkawinan Indonesia. Cet. Ke-1. Yogyakarta: Lintang Rasi Aksara Books. 2016.

Ibnu Rusyd. t.th. Bidayalul Mujtahid. Surabaya: Al-Hidayah.

Kamal Mukhtar. Asas-asas Hukum Islam tentang Perkawinan. Jakarta: Bulan Bintang. 1985.

Moleong Lexy J. Metode Penelitian Kualitatif. Bandung: Remaja Rosdakarya. 2000.

Salamah, Wawancara, 30 Juli 2018.

Soemiyati. Hukum Perkawinan Islam dan Undang-Undang Perkawinan. Yogyakarta: Liberty. 1997.

Soemiyati. Hukum Perkawinan dan Undang-Undang Perkawinan Nomor 1 Tahun 1974. Yogyakarta: Liberty. 1997.

Sugiyono. Metode Penelitian kuantitatif, kualitatif, dan $R \& D$. Bandung: Alfabeta. 2009.

Sulaiman Ibn Muhammad Ibn Umar al-Bujairimi. Al-Bujairimi 'ala al-Khatib. Juz IV. Beirut: Dar al-Kutub al-Ilmiyah. 1996.

Suryabrata Sumadi. Metode Penelitian. Jakarta: Raja Grafindo Persada. 2010.

Thayib Anshari. Struktur Rumah Tangga Muslim. Surabaya: Risalah Gusti. 1991.

Tim Penyusun. Undang-Undang Perkawinan di Indonesia. Surabaya: Arkola. 1974.

Tim Penyusun. Undang-Undang Perkawinan di Indonesia. Surabaya: Arkola. 2005.

Undang-Undang Nomor 16 Tahun 2019 perubahan atas Undang-Undang Nomor 1 Tahun 1974 tentang Perkawinan.

Yanggo Chuzaimah T. dan A. Hafiz Anshari A. Z. (Ed.). Problematika Hukum Islam Komtemporer. Jakarta: Sinar Grafika. 2000. 